\title{
ADRENAL NECROSIS IN GENERALIZED HERPES SIMPLEX
}

\author{
BY \\ R. T. BRAIN and R. C. B. PUGH and J. A. DUDGEON \\ From The Hospital for Sick Children, Great Ormond Street, and St. George's Hospital Medical School, London
}

(RECEIVED FOR PUBLICATION AUGUST 30, 1956)

For a number of years after the first isolation of a virus from a case of human keratitis (Grüter, 1913, quoted by Lowenstein, 1919) the true nature of herpes remained in doubt because it did not seem to follow the hitherto accepted pattern of infectious disease (Doerr, 1938). But in 1938 Dodd, Johnston and Buddingh showed that herpes simplex virus could frequently be recovered from the saliva of cases of ulcerative stomatitis in children (Dodd et al., 1938). These findings were confirmed the following year by Burnet and Williams who showed that after the acute phase of the illness herpes-neutralizing antibody appeared for the first time in the blood (Burnet and Williams, 1939). It was thus possible to distinguish between a primary herpetic infection in an individual with no previous immunity and a recurrent infection in which antibody was already present (Andrewes and Carmichael, 1930) and from these observations the modern concept of herpes as an infectious disease has developed (McNair Scott, 1954).

As in many other virus diseases inapparent infection is extremely common and it has been estimated that as many as 90 to $95 \%$ of all herpetic infections are asymptomatic (McNair Scott, 1954; Blank and Rake, 1955). In symptomatic infections the clinical picture is extremely variable both as regards site of infection and severity (Brain, 1956) and, also, children with eczema are particularly prone to develop a generalized infection due to virus dissemination. This is usually referred to as Kaposi's varicelliform eruption (K.V.E.) or eczema herpeticum. Many of these cases run a severe course (Jackson and Dudgeon, 1951). In recent years another and even more severe form of herpes has been recognized in which there is a fulminating infection with widespread visceral necrosis. Zuelzer and Stulberg first reported from the United States eight such patients among whom the most gross and widespread visceral lesions were found in a group of premature infants (Zuelzer and Stulberg, 1952). Subsequently, in this country, cases have been recorded of generalized herpes with hepatitis and encephalitis in newborn twins (France and Wilmers, 1953) and disseminated herpes with hepatic necrosis and isolation of virus from the liver at necropsy (Pugh, Newns and Dudgeon, 1954). However, visceral necrosis is not confined to this group of fulminating cases but may also occur in K.V.E. An instance of this was the finding of typical viral and atypical necrotic visceral lesions in a fatal case of K.V.E. seen in a small outbreak of herpes in a children's ward (Pugh, Dudgeon and Bodian, 1955).

The case described here is another example of fatal K.V.E. occurring in a ward for the treatment of skin disease, in which there were almost certainly two other cases of herpes simplex infection at the same time. After an illness which initially ran a not unusual course sudden deterioration with clinical evidence of adrenal insufficiency developed. At necropsy many necrotic lesions were discovered in both adrenals and herpes simplex virus was recovered from the adrenals, skin, brain, lymph nodes and uvula.

\section{Case Report}

P.G., a boy aged 9 months, was admitted to hospital on July 14, 1954, with a history of eczema, superimposed on a napkin erythema, since the age of 3 months. On admission weeping and crusted eczematous lesions were present on the trunk, face and limbs with enlargement of the lymph nodes but without obvious signs of secondary pyogenic infection. He was treated with saline baths and cooling lotions and for a time the skin lesions improved considerably. Later a relapse occurred and cortisone, $50 \mathrm{mg}$. daily, was given for three days but without effect. However, by the beginning of September the skin eruption had cleared except for some weeping lesions on the face which were then successfully treated with $1 \%$ hydrocortisone ointment locally.

On October 11 two other children (J.D. and A.W.) with 'infected eczema' were admitted to the ward and the possibility that they were suffering from herpes simplex infection was considered. In one case (J.D.) cytological evidence of herpes was found and the virus was sub- 


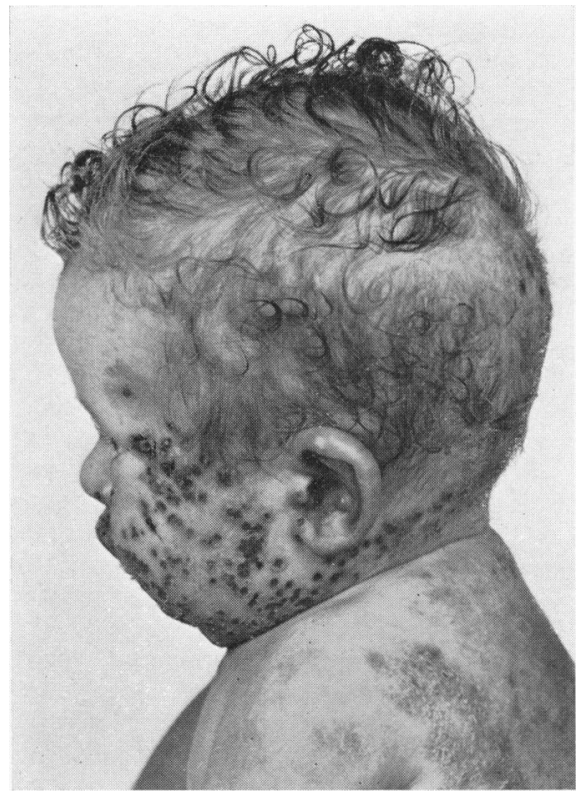

Fig. 1.-The appearance of the skin lesions on the seventh day of the illness.

sequently isolated from the skin, but in the other (A.W.) the results of examination of the smears were equivocal. At this stage it was decided to give all patients in the ward gamma globulin as a prophylactic and, accordingly, this child (P.G.) was given $6 \mathrm{ml}$. intramuscularly (500 mg.) on October 15. On the following day he developed a typical herpetic eruption on the face, back and legs. His white blood count was 15,500 per c.mm. (neutrophils $87 \%$ ) and coagulase-positive staphylococci and Streptococcus haemolyticus were cultured from the skin lesions. Antibiotic treatment was started and during the subsequent 10 days the child received $3.4 \mathrm{~g}$. of aureomycin, $8 \frac{1}{2}$ million units of 'penidural' and $2 \mathrm{~g}$. of 'gantrisin'.
A further dose of gamma globulin $(500 \mathrm{mg}$.) was given on October 18. The diagnosis of K.V.E. was confirmed by the finding of multinucleate epithelial cells in the vesicular lesions. The appearance of the skin condition at this time is shown in Fig. 1.

By October 20 the child's temperature had settled and his general condition was slowly improving. But five days later there was a sudden deterioration and collapse with dyspnoea, a distended abdomen and signs of severe shock. Investigations showed a total white blood count of 5,600 per c.mm. (neutrophils $65 \%$ ), normal blood chemistry and a sterile blood culture; the blood sugar level was also normal. The baby did not respond to treatment, the systemic collapse persisted and he died on October 27, 1954, 11 days after the onset of K.V.E. Fig. 2 illustrates the course of the illness.

\section{Laboratory Investigations}

The methods of investigation used in this case have been described fully elsewhere (Dudgeon, 1951; Pugh et al., 1955). The initial clinical diagnosis of herpes simplex was confirmed by the finding of multinucleate epithelial cells in scrapings from the vesicular skin lesions and by the isolation of herpes simplex virus by animal and egg inoculations. At necropsy, performed six hours after death, lesions suggestive of focal necrosis were noticed in both adrenals. The virus isolated from the various viscera was identified by histological examination and by the neutralization test in the chick-embryo. The results of these inoculations are summarized in the Table. The outstanding feature was the large amount of infective virus in the adrenals.

The virus isolated from skin, adrenals and brain was neutralized by specific herpes antiserum. Focal necrotic lesions with intranuclear inclusions were also found in the infected animal tissues. Neutralizing antibody (titre $1: 16$ ) was found in the child's serum collected at necropsy (11th day of the disease). Electrophoretic analysis of this same serum was carried out by Professor N. Martin at St. George's Hospital. The findings were: 'Pattern resembled that often seen in nephrosis, having a

TABLE

ISOLATION OF VIRUS FROM THE TISSUES

\begin{tabular}{|c|c|c|c|c|c|c|c|}
\hline \multirow{2}{*}{\multicolumn{4}{|c|}{ Inoculum }} & \multicolumn{2}{|c|}{$\begin{array}{c}\text { Chick-embryo Chorio-allantois } \\
(0.1 \mathrm{ml} .)\end{array}$} & \multicolumn{2}{|c|}{$\begin{array}{l}\text { Suckling Mice } \\
\text { (intracerebral inoculation } 0.05 \mathrm{ml} \text { ) }\end{array}$} \\
\hline & & & & Focal Lesions & $\begin{array}{l}\text { Average No. } \\
\text { per Membrane* }\end{array}$ & Symptoms & $\begin{array}{c}\text { Mortality Rate on } \\
\text { Day } 7 \dagger\end{array}$ \\
\hline $\begin{array}{l}\text { Ante-mortem } \\
\text { Skin swab } \\
\text { Vesicle fluid }\end{array}$ & $\begin{array}{l}\cdots \\
\cdots\end{array}$ & $\begin{array}{l}\cdots \\
\cdots\end{array}$ & $\begin{array}{l}\cdots \\
\cdots\end{array}$ & $\begin{array}{l}+ \\
+\end{array}$ & $\begin{array}{l}100-200 \\
100-200\end{array}$ & $\begin{array}{l}+ \\
+\end{array}$ & $\begin{array}{l}6 / 6 \\
6 / 6\end{array}$ \\
\hline 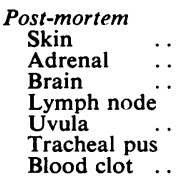 & $\begin{array}{l}\ldots \\
\cdots \\
\cdots \\
\cdots \\
\cdots \\
\cdots\end{array}$ & $\begin{array}{l}\cdots \\
\cdots \\
\cdots \\
\cdots \\
\cdots\end{array}$ & $\begin{array}{l}\cdots \\
\cdots \\
\cdots \\
\cdots \\
\cdots \\
\cdots\end{array}$ & $\begin{array}{c}+ \\
++ \\
+ \\
+ \\
+ \\
-\end{array}$ & $\begin{array}{c}100-200 \\
\text { Confluent } \\
5-10 \\
5-10 \\
5-10 \\
0 \\
0\end{array}$ & $\begin{array}{c}+ \\
++ \\
+ \\
+ \\
+ \\
-\end{array}$ & $\begin{array}{c}5 / 6 \\
12 / 12 \\
3 / 9 \\
4 / 8 \\
5 / 6 \\
0 / 6 \\
0 / 6\end{array}$ \\
\hline
\end{tabular}

* Number of focal lesions per membrane 48 hours after inoculation.

$\uparrow$ Mortality rate in a litter of suckling mice on 7 th day after inoculation. 
low albumin and high alpha globulin; the beta and gamma globulins being within normal range.' In interpreting these results it has to be recalled that $1,000 \mathrm{mg}$. gamma globulin had been given therapeutically 12 days before death.

PHILIP G. AGED:I2 MONTHS

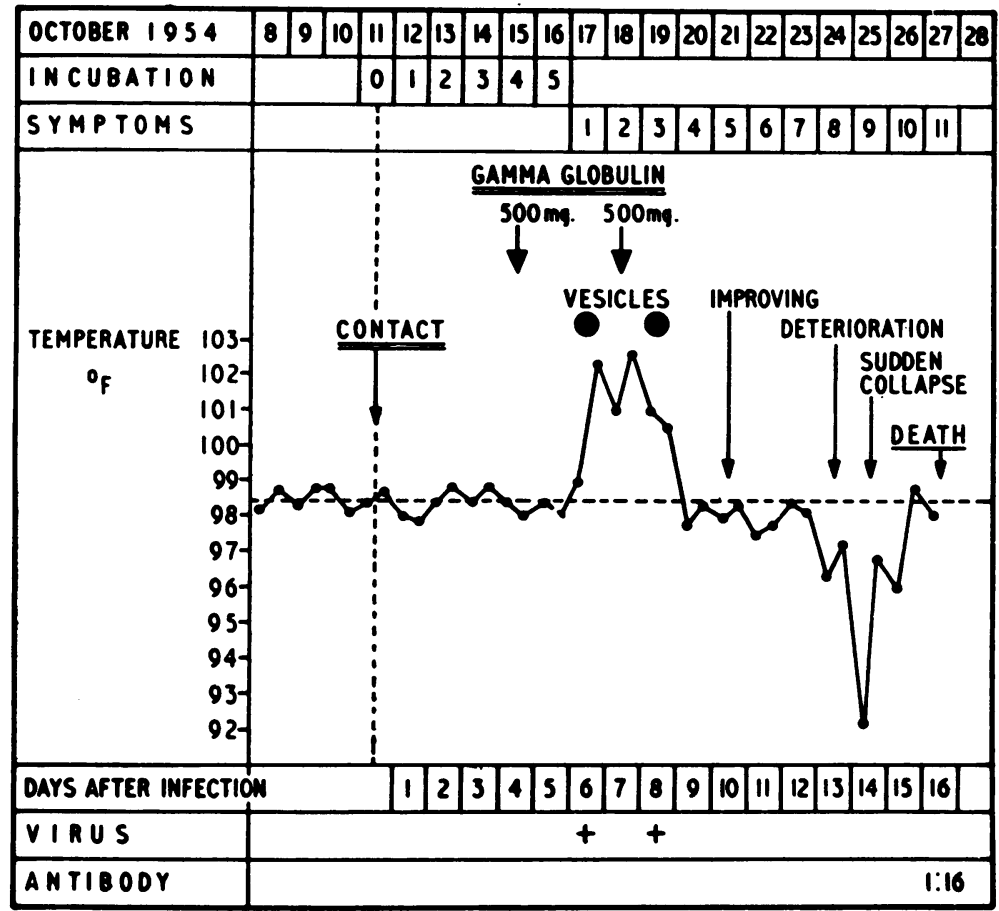

FIG. 2.-Chart showing details of the clinical course and laboratory findings.

\section{Post-mortem Appearances}

The necropsy was performed six hours after death. The body was that of a male infant in good nutritional condition (height 30 in., body weight 19 lb.). There were extensive weeping and crusting eczematous lesions of the skin of the scalp, ears, face, neck, flanks, penis and scrotum, glutei and the whole of both lower limbs from the level of the inguinal ligaments downwards. Some lesions showed scaling and many of the smaller ones had serpiginous outlines. Flaccid, and sometimes umbilicated, vesicular lesions were present on both lower eyelids, in the right groin and on the fifth left finger. There was irregular desquamation of the skin of the upper limbs.

The brain weighed $950 \mathrm{~g}$. and was intensely congested and moderately oedematous with some flattening of the convolutions at the occipital pole. Section confirmed the presence of congestion and oedema but did not reveal any other significant change. There was punctate congestion of the grey matter of the spinal cord. The right side of the heart was dilated. Rounded and irregularly- shaped areas of superficial ulceration, measuring up to $0.5 \mathrm{~cm}$. in diameter, were found at the tip of the tongue and on the nasal surface and tip of the uvula. The pharynx and trachea contained rather viscid brownish mucoid exudate. The lungs were congested and oedematous without any obvious consolidation. The adrenals were of normal size and shape and their external surfaces were studded with large numbers of rounded or oval yellowish-white lesions, superimposed on a dark, reddish-purple background. Individually these measured between 0.1 and $0.3 \mathrm{~cm}$. in diameter and were entirely cortical in situation, sometimes occupying the full thickness of the cortex and in other instances apparently lying more superficially (Fig. 3). The cervical, para-aortic, iliac and inguinal lymph nodes were enlarged and hyper-plastic. No other relevant abnormalities were found on internal examination.

\section{Histology}

Sections taken from all areas of the skin showed changes consistent with a chronic stage of eczema, with acanthosis, broadening of the rete pegs, hyperkeratosis and some lymphocytic infiltration in the more superficial parts of the corium. In addition, herpetic lesions were seen in all stages of evolution, varying from areas of early intra-epidermal vesicle formation to large areas of fullthickness necrosis of the epidermis. In all instances the lesions had clearly defined margins, showed a variable degree of secondary infection and had a superficial covering of crusted material. Unless there was a marked degree of secondary infection, polymorph infiltration was not a very conspicuous feature in any of the lesions. At the periphery of the vesicles and necrotic areas the intact epithelial cells frequently were multinucleate and enlarged-the so-called 'ballooned cells'-and both basophilic and acidophilic intranuclear inclusions, characteristic of herpes simplex, were seen. Similar necrotic and vesicular lesions, with intranuclear inclusions, occurred in the tongue and uvula, whilst in the lower part of the oesophagus there was a zone of full-thickness necrosis of the epithelium due to a local herpetic lesion. Both adrenals contained numerous clearly demarcated areas of recent coagulative parenchymal necrosis affecting the full thickness of the cortex. At the margins of the lesions there were small collections of polymorphs, together with some pyknotic nuclear debris (Fig. 4). In this area, too, 

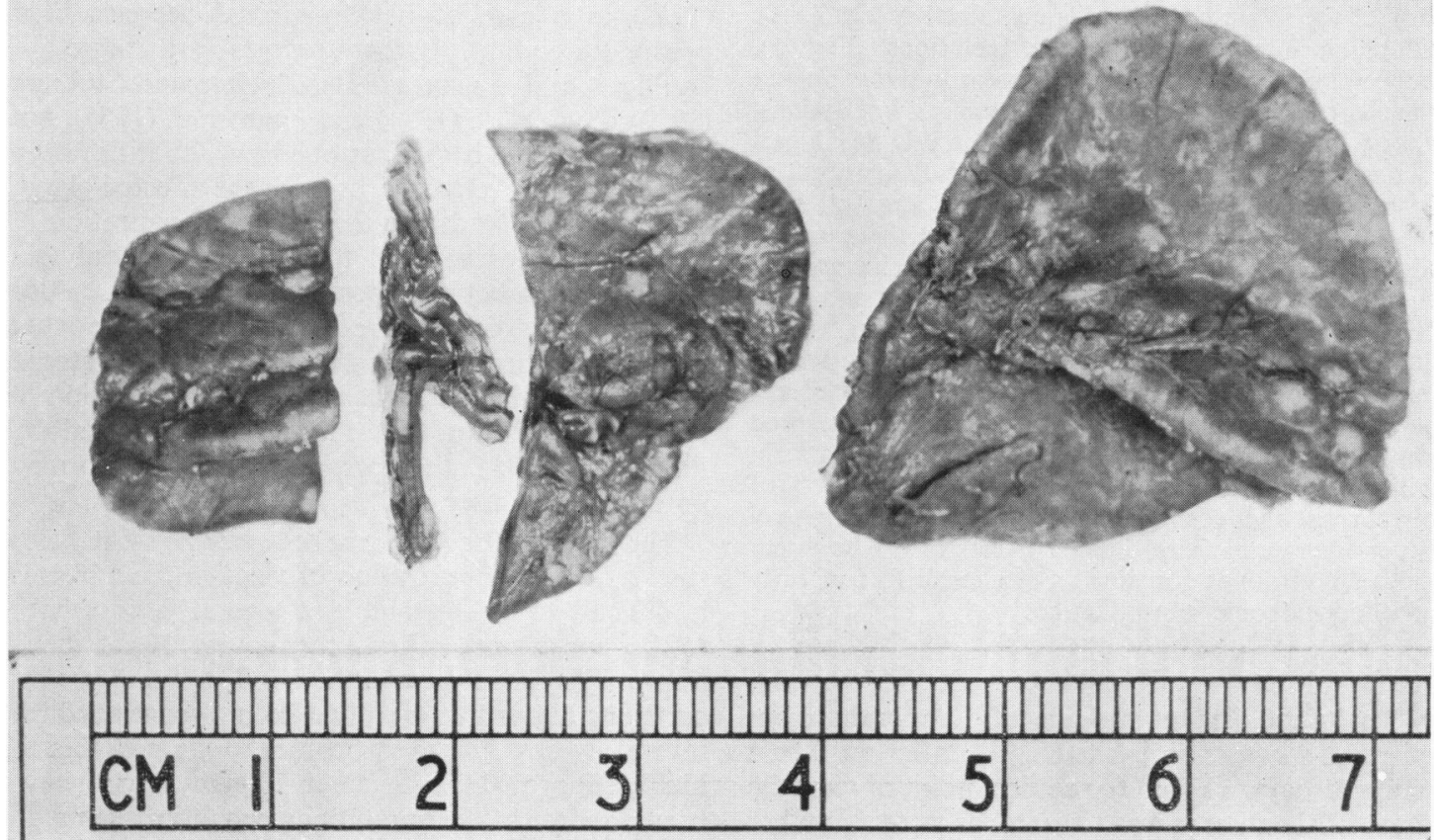

Fig. 3.-Adrenals: the numerous rounded pale lesions are visible on the external and cut surfaces.

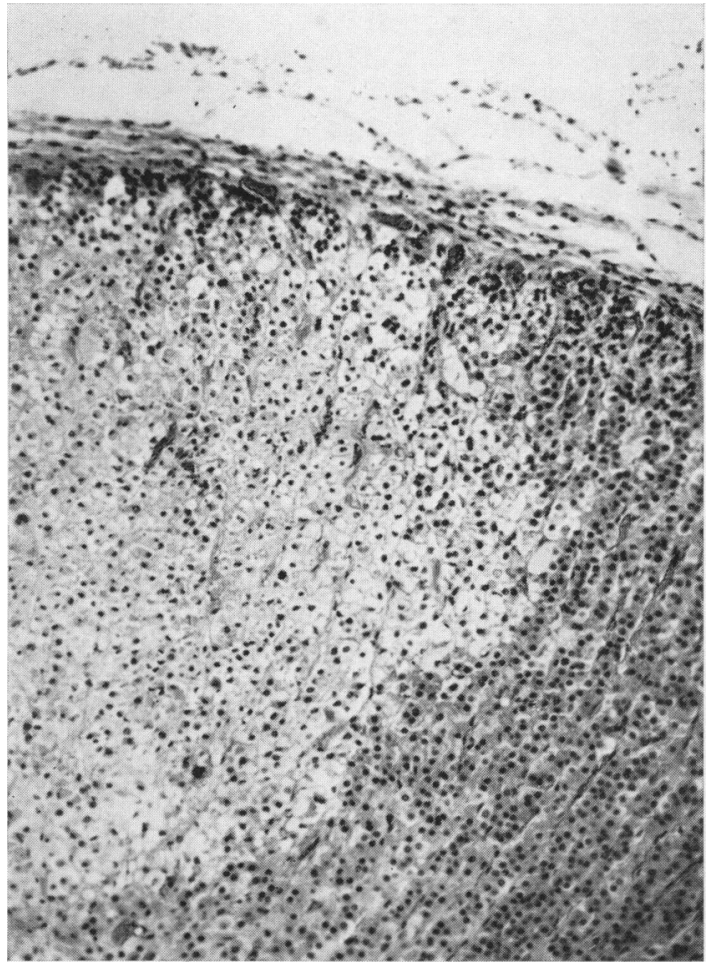

FIG. 4.-Adrenal: the margins of one of the viral lesions showing the clear line of demarcation between necrotic and living tissue. Haematoxylin and eosin $\times 160$.

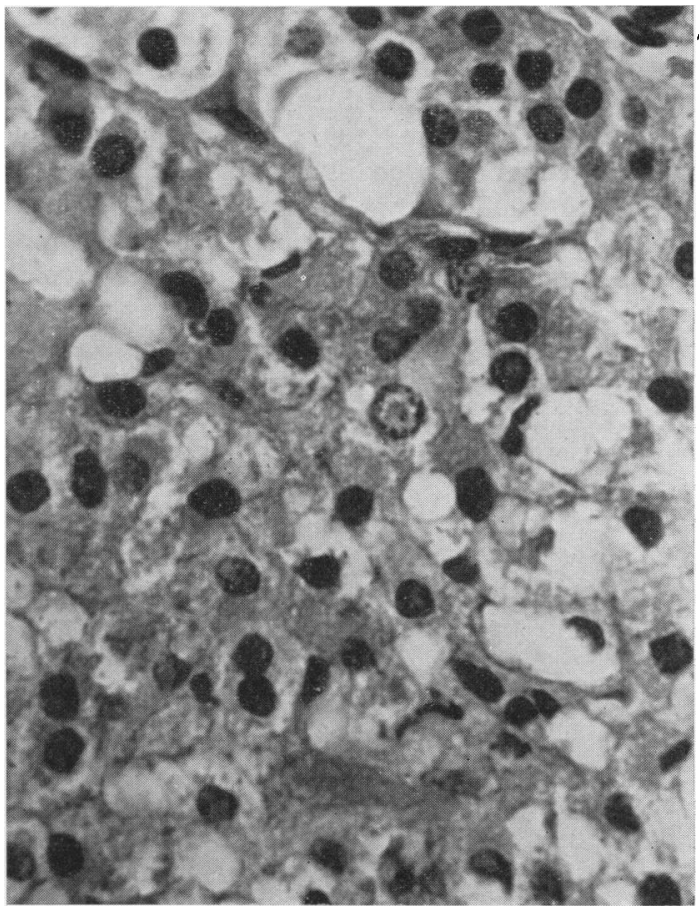

FIG. 5.-Adrenal: high-power view of the margin of one of the necrotic lesions showing a typical intranuclear inclusion in the centre of the field.

Haematoxylin and eosin $\times 500$. 
many of the intact cortical cells contained basophilic or acidophilic intranuclear herpetic inclusions (Fig. 5). Many sections from representative areas in the brain and spinal cord failed to reveal any specific viral lesions, although at all levels there was a variable meningeal reaction, consisting of congestion and small aggregations of lymphocytes, as well as parenchymal damage, with chromatolysis of a considerable number of the ganglion cells. This was accompanied by a diffuse increase of round lymphocyte-like cells in the parenchyma and some perivascular cuffing of a few of the penetrating vessels with lymphocytes. These changes were particularly well marked in the cord, medulla and pons. No inclusions could be found. The lymph nodes showed well marked lymphoid hyperplasia and some patchy sinus catarrh, whilst in some nodes there was an accumulation of polymorphs and eosinophilic debris in the peripheral sinuses; no specific viral lesions were seen. The upper lobes of both lungs contained a few small foci of early bronchopneumonic consolidation.

\section{Discussion}

This infant died at the age of 12 months from generalized herpes simplex (K.V.E.) after an illness lasting 11 days. From the clinical point of view the course of the disease was unusual, as were a number of the laboratory findings.

The baby became infected with herpes simplex virus whilst in hospital for treatment of eczema and for just over a week the disease ran a perfectly normal course for an attack of K.V.E. But on the eighth day after the probable date of exposure, when the infection appeared to be resolving, the child suddenly became acutely ill again with clinical signs of adrenal insufficiency which persisted until death two days later. This is, in our experience, a most uncommon clinical course for a generalized herpetic infection in a child of this age. Moreover, we have not been able to find any similar accounts in the literature except that, in the series reported by Zuelzer and Stulberg (1952), three of the cases showed signs of acute shock just before death. In most cases of K.V.E. the severity of the infection is related to the size of the area of skin involved and to the toxaemia resulting from both viral and heavy secondary bacterial infection. In this case the skin lesions, although extensive, were healing when the systemic collapse occurred, so that it seemed certain that some serious complication, such as widespread visceral involvement or massive invasion of an important internal organ, had occurred. Postmortem examination showed that this was in fact the case for there were viral lesions in many tissues, with particularly severe and extensive involvement of the adrenals.

Adrenal lesions are by no means unknown in herpes simplex and were first described by Hass
(1935) in a case of hepato-adrenal necrosis in a premature infant. Other reports are those of Quilligan and Wilson (1951), Zuelzer and Stulberg (1952), Pugh et al. (1954) and Pugh et al. (1955), but this present case is the first one in which it has been possible to recover the virus from the affected gland. This may well be due to the heavy concentration of virus in the adrenal and to the fact that only six hours elapsed between death and necropsy. Also special precautions were taken to ensure that material for virus isolation was collected and stored under optimal conditions. In this connexion it may be significant that in the case reported by Pugh et al. (1955) the necropsy was not performed until 20 hours after death.

The reason for this marked involvement with such a heavy concentration of virus in the adrenals is difficult to understand and several factors have to be considered. First, the course of the infection might have been influenced by the use of cortisone but as this drug had been discontinued for several weeks before exposure to herpes this is highly improbable. Secondly, there might have been a defect in the immunity mechanism such as is known to occur in prolonged generalized vaccinia (Laurance, Cunliffe and Dudgeon, 1952; Hall, Cunliffe and Dudgeon, 1953), a condition characterized by a very much longer course with widespread visceral necrosis and associated with a complete failure of antibody formation and in some cases with agammaglobulinaemia (Keiden, McCarthy and Haworth, 1953). Again this seems unlikely in view of the short length of the illness, the presence of an inflammatory reaction in the skin and affected organs and the finding of a normal gamma globulin level in the blood. The diagnosis of agammaglobulinaemia and hypogammaglobulinaemia in the first year of life is unquestionably difficult as it seems probable that there is a condition of transient hypogammaglobulinaemia which arises from tardy development of gamma globulin rather than from any true defect in sensitivity. This transient condition is not, so far as we know, sexlinked and therefore appears to be different from the genetic agammaglobulinaemia described by Janeway et al. (Janeway, Apt and Gitlin, 1953). The normal range for gımma globulin for a 9-month-old child lies somewhere between 400 and $700 \mathrm{mg}$. per $100 \mathrm{ml}$. plasma. The total circulating globulin for a child of this size probably is a little over $1 \mathrm{~g}$. If this child had been suffering from hypogammaglobulinaemia in the first instance it is quite possible that the $1 \mathrm{~g}$. gamma globulin which was given therapeutically would have raised the calculated level to within the normal range, thereby masking an under- 
lying hypogammaglobulinaemia (Martin, 1956). Interpretation of the serological test in which neutralizing antibody was found in a titre of $1: 16$ is also complicated by the injection of $1,000 \mathrm{mg}$. gamma globulin only a few days before the serum was collected at necropsy. Moreover, this coincided with the time that antibody can usually be detected in significant titre in herpetic infections and, on the face of it, it seems probable that some at least of this antibody resulted from active immunity.

The only conclusion that can be drawn is that for some reason the adrenals were the site of an unusual degree of virus multiplication, as a result of which their normal activity was impaired and the normal response to infection was overwhelmed by the concentration of infective virus produced.

The possibility that changes in the central nervous system might have contributed to death has also to be considered, particularly when it is recalled that the virus was recovered from the brain. Although no specific histological evidence of herpes in the form of intranuclear inclusions could be found, it is probable that the inflammatory changes that were present resulted from early viral invasion. Despite this there is little doubt that the adrenal lesions were more lethal than those in the nervous system.

It now has to be considered what steps can usefully be taken to reduce the risks of infection in subsequent cases of infantile eczema. Children with eczema, and particularly the very young ones, are so susceptible to herpetic infection that it would seem advisable to use every means possible to reduce the risk of exposure and subsequent infection. In a series of 16 cases of K.V.E. seen at The Hospital for Sick Children, 10 were under 1 year of age and nine were classed as seriously ill, although none died (Jackson and Dudgeon, 1951). In a more recent review of all cases of K.V.E. due to herpes simplex virus seen at this hospital from 1948 to 1956 , a total of 36 cases was found of which approximately the same proportion were seriously ill. There were three deaths, including the case now reported (Brain, 1956). The source of infection is of the greatest importance and, in exactly the same way as efforts are made to avoid bringing eczematous children into contact with vaccinia virus by postponing vaccination, so should the risk of exposure to herpes virus be minimized. Clearly this may be difficult as is shown in the case described here, where two cases of 'infected eczema' were admitted to the ward and in at least one of whom the diagnosis of herpes was confirmed later. Moreover, barrier nursing methods were in use in the ward. It is known from experience that the degree of contact need not be very close and, even under the best possible conditions, infection can be spread from one cubicle to another. The danger from recurrent herpes in those in close contact with these children, such as parents and medical and nursing staffs, is well known but there is always the added danger of transferring infection from one case to another unless the most scrupulous attention is paid to detail. It would probably be advisable to regard all cases of 'infected eczema' as potentially infected with herpes virus unless proved otherwise, and especially while laboratory tests are being carried out or where the results are equivocal.

The use of gamma globulin must also be discussed; in this case $1,000 \mathrm{mg}$. given four to seven days after exposure failed to prevent infection and the most likely explanation is that it was given too late. The incubation period of herpes varies between four and seven days but by the time the first dose was given (see Fig. 2) virus multiplication was almost certainly well advanced and, moreover, at this stage the virus would be largely intracellular and therefore beyond the reach of antibody. Gamma globulin, which contains herpes-neutralizing antibody, should prevent infection if given before or immediately after exposure; so that, depending on the individual circumstances and the age of the child, passive immunization with gamma globulin should be considered for cases of infantile eczema on admission to hospital. A reasonable dosage would be $0.1 \mathrm{ml}$. per $\mathrm{lb}$. of body weight with a further similar dose four to six weeks later if the stay in hospital is likely to be prolonged. The chances of sensitization from repeated injections of gamma globulin are negligible. Passive immunization before exposure combined with chemotherapy to control secondary infection should reduce the risk of a generalized infection and the resulting toxaemia in infants at this vulnerable age.

\section{Summary}

A case is described of fatal generalized herpes simplex with extensive adrenal necrosis in a boy 9 months of age. An unusual feature was the sudden collapse with signs of adrenal insufficiency that occurred on the eighth day of the illness. Post-mortem examination showed evidence of visceral involvement with a particularly heavy concentration of virus in the adrenals. It is suggested that in certain circumstances infants or young children with eczema and likely to be exposed to herpetic infection should receive passive immunization with gamma globulin.

We should like to express our thanks to Dr. Arild Harboe of the State Institute of Public Health, Oslo 
(Research Fellow, Virus Laboratory, St. George's Hospital Medical School, September-December, 1953), for great assistance with the virus isolation experiments, and to Professor Nicholas Martin, Department of Chemical Pathology, St. George's Hospital Medical School, for carrying out the electrophoretic analysis and for much helpful advice and criticism.

\section{REFERENCES}

Andrewes, C. H. and Carmichael, E. A. (1930). Lancet, 1, 857. Blank, H. and Rake, G. (1955). Viral and Rickettsial Diseases of the Skin, Eye and Mucous Membranes of Man. Boston.

Skin, Eye and Mucous Membranes
Brain, R. T. (1956). Brit. med. J., 1, 1061.

Burnet, F. M. and Williams, S. W. (1939). Med. J. Aust., 1, 637.

Dodd, K., Johnston, L. M. and Buddingh, G. J. (1938). J. Pediat., 12, 95

Doerr, R. (1938). In Handbuch der Virusforschung, ed. Doerr, R. and Hallauer, C., Vol. 1, p. 41. Vienna

Dudgeon, J. A. (1951). Gt Ormond Str. J., 1, no. 1, p. 1.

Dudgeon, J. A. (1951). Gt Ormond Str. J., 1, no. 1, p. 1.
France, N. E. and Wilmers, M. J. (1953). Lancet, 1, 1181.
Grüter (1913). Quoted by Löwenstein (1919). Personal com-

munication.
Hall, G. F. M., Cunliffe, A. C. and Dudgeon, J. A. (1953). J. Path. Bact., 66, 25.

Hass, G. M. (1935). Amer. J. Path., 11, 127.

Jackson, A. D. M. and Dudgeon, J. A. (1951). Gt Ormond Str. J., 1 , no. 2 , p. 125

Janeway, C. A., Apt, L. and Gitlin, D. (1953). Trans. Ass. Amer. Phys., 66, 200.

Keiden, S. E., McCarthy, K. and Haworth, J. C. (1953). Archives of Disease in Childhood, 28, 110 .

Laurance, B., Cunliffe, A. C. and Dudgeon, J. A. (1952). Ibid., 27,482 .

Löwenstein, A. (1919). Munch. med. Wschr., 66, 769.

Martin, N. H. (1956). Personal communication.

Pugh, R. C. B., Dudgeon, J. A. and Bodian, M. (1955). J. Path. Bact., 69, 67.

- Newns, G. H. and Dudgeon, J. A. (1954). Archives of Disease in Childhood, 29,60 .

Quilligan, J. J. and Wilson, J. L. (1951). J. Lab. clin. Med., 38, 742.

Scott, T. F. McNair (1954). New Engl. J. Med., 250, 183.

Zuelzer, W. W. and Stulberg, C. S. (1952). Amer. J. Dis. Child., 83, 421 . 